University of Arkansas, Fayetteville

ScholarWorks@UARK

$6-2010$

\title{
What Explains the Gender Gap in Financial Literacy? The Role of Household Decision-Making
}

\author{
Raquel Fonseca \\ RAND Corporation, Santa Monica \\ Kathleen J. Mullen \\ RAND Corporation, Santa Monica \\ Gema Zamarro \\ University of Arkansas, Fayetteville, gzamarro@uark.edu \\ Julie Zissimopoulos \\ RAND Corporation, Santa Monica
}

Follow this and additional works at: https://scholarworks.uark.edu/edrepub

Part of the Educational Assessment, Evaluation, and Research Commons, Educational Leadership Commons, Finance Commons, and the Other Educational Administration and Supervision Commons

\section{Citation}

Fonseca, R., Mullen, K. J., Zamarro, G., \& Zissimopoulos, J. (2010). What Explains the Gender Gap in Financial Literacy? The Role of Household Decision-Making. Education Reform Faculty and Graduate Students Publications. Retrieved from https://scholarworks.uark.edu/edrepub/110

This Article is brought to you for free and open access by the Education Reform at ScholarWorks@UARK. It has been accepted for inclusion in Education Reform Faculty and Graduate Students Publications by an authorized administrator of ScholarWorks@UARK. For more information, please contact scholar@uark.edu. 


\title{
WORKING \\ $P$ A P E R
}

\section{What Explains the Gender Gap in Financial Literacy?}

\section{The Role of Household Decision- Making}

\author{
RAQUEL FONSECA \\ KATHLEEN J. MULLEN \\ GEMA ZAMARRO \\ JULIE ZISSIMOPOULOS
}

This product is part of the RAND Labor and Population working paper series. RAND working papers are intended to share researchers' latest findings and to solicit informal peer review. They have been approved for circulation by RAND Labor and Population but have not been formally edited or peer reviewed. Unless otherwise indicated, working papers can be quoted and cited without permission of the author, provided the source is clearly referred to as a working paper. RAND's publications do not necessarily reflect the opinions of its research clients and sponsors.

RAND ${ }^{\circledR}$ is a registered trademark.
WR-762

June 2010

This paper series made possible by the NIA funded RAND Center for the Study of Aging (P3OAG012815) and the NICHD funded RAND Population Research Center (R24HD050906). 


\title{
What Explains the Gender Gap in Financial Literacy? The Role of Household Decision-Making
}

\author{
Raquel Fonseca, Kathleen Mullen, Gema Zamarro, and Julie Zissimopoulos ${ }^{1}$ \\ RAND
}

June 2010

\begin{abstract}
Research has shown that financial illiteracy is widespread among women, and that many women are unfamiliar with even the most basic economic concepts needed to make saving and investment decisions. This gender gap in financial literacy may contribute to the differential levels of retirement preparedness between women and men. However, little is known about the determinants of the gender gap in financial literacy. Using data from the RAND American Life Panel, we examined potential explanations for the gender gap including the role of marriage and division of financial decision-making among couples. We found that differences in the demographic characteristics of women and men did not explain much of the financial literacy gap, whereas education, income and current and past marital status reduced the observed gap by around $25 \%$. Oaxaca decomposition revealed the great majority of the gender gap in financial literacy is not explained by differences in covariates - characteristics of men and women - but due to coefficients, or how literacy is produced. We did not find strong support for specialization in financial decision-making within couples by gender. Instead, we found that decision-making within couples was sensitive to the relative education level of spouses for both women and men.
\end{abstract}

\footnotetext{
${ }^{1}$ We gratefully acknowledge funding from RAND's Roybal Center for Financial Decision Making. Correspondence: Kathleen Mullen, RAND Corporation, 1776 Main Street, P.O. Box 2138, Santa Monica, CA 90407-2138. Tel: 310-393-0411 x6265. E-mail: kmullen@rand.org.
} 


\section{Introduction}

Women tend to live longer than men, have shorter work experiences, lower earnings and levels of pension or survivors' benefits. These factors put women at a higher risk than men of having financial problems (e.g. Weir and Willis, 2000) and of approaching retirement with little or no savings. Indeed, unmarried, particularly divorced, women near retirement age have substantially lower wealth levels than married couples and unmarried men and the difference is only partially explained by lower levels of permanent earnings and labor force attachment (Levine et al., 2002; Zissimopoulos et al., 2008). A contributing factor to low wealth levels of divorced women compared to men near retirement may be a lack of adequate financial literacy.

There is a burgeoning literature documenting low levels of financial literacy populationwide and the relationship between literacy and savings behavior (e.g. Bernheim and Garrett 2003, Bernheim et al. 2001, Lusardi and Mitchell 2006, 2007). Lusardi and Mitchell (2006) document that only about one-half of adults near retirement age in the United States were able to answer basic questions about compound interest and inflation. Financial illiteracy, however, is even more widespread among women than men, particularly familiarity with basic economic and financial concepts (Lusardi and Mitchell, 2008; Zissimopoulos et al., 2008, Chen and Volpe, 2002). ${ }^{2}$ Zissimopoulos et al., (2008) find that less than 20 percent of middle-aged collegeeducated women were able to answer a basic compound interest question compared to about 35 percent of college-educated males of the same age group. Chen and Volpe (2002) find similar gender difference among women at younger ages that was unexplained by differences in majors, class rank, work experience and age.

Changing demographic trends and types of financial decisions being made increase the importance of understanding what accounts for the low levels of financial knowledge and literacy among women and what role financial literacy plays in determining savings behavior. Increasing rates of divorce and lower remarriage rates imply higher rates of unmarried women at retirement age than in the past. Moreover, shifts in pension plan types from defined benefit to defined contribution imply individuals are taking more responsibility for their retirement security. At the same time the growing number of financial instruments available for financing a

\footnotetext{
${ }^{2}$ Lusardi and Mitchell (2008) also found women were less likely to have undertaken retirement planning than men. Clark et al. (2004) found that women were more likely to respond to financial education programs with increased confidence in attaining retirement goals than men.
} 
home or extracting equity from an existing home imply some key decisions are becoming more complex.

Although there is general agreement in the empirical literature that women have lower levels of financial knowledge than men, less is understood about the magnitude of this difference, the factors associated with the difference, and how this translates into behavior. In this paper, we contribute to our understanding of the gap in financial knowledge between women and men by investigating the socio-economic and demographic factors associated with the gap and quantifying the gap using Oaxaca Decomposition techniques. We investigate the role of division of labor in financial decision-making within a household. ${ }^{3}$ That is, we investigate decision-making within a couple by gender and how this correlates with levels of financial literacy and education level of each partner.

For the analysis we use existing data on financial literacy from RAND American Life Panel (ALP) and data we collected on decision making within the household. We found that differences in the demographic characteristics of women and men did not explain much of the financial literacy gap, whereas education, income and current and past marital status reduced the observed gap by around $25 \%$. Oaxaca decomposition revealed the great majority of the gender gap in financial literacy is not explained by differences in covariates - characteristics of men and women - but due to coefficients, or how literacy is produced. We also found that among couples, there was no discernible pattern of financial decision-making along gender lines and one's own financial responsibilities increased as his or her education level increased relative to his or her spouse's education level for both men and women. Finally, only among men was more financial decision-making correlated with higher financial literacy.

The rest of the paper is organized as follows. Section 2 describes our dataset and variables of interest. The main summary statistics are also presented in this section. Section 3 describes quantifications of the gender gap on financial literacy and studies which factors mitigate the observed gender differences. Section 4 presents our results of the analysis of the role of household specialization and the division of labor among couples. Finally, Section 5 presents our conclusions.

\footnotetext{
${ }^{3}$ There is an extensive literature on division of labor within households (see Becker, 1985, among others).
} 


\section{Data}

\subsection{The RAND American Life Panel}

To conduct this research, we used data from the RAND American Life Panel (ALP). The ALP consists of over 2,500 respondents ages 18 and over who are interviewed periodically over the Internet. The ALP respondents are recruited from respondents of the University of Michigan's Survey Research Center Monthly Survey (MS). Respondents do not need their own Internet access to participate in the panel; those without Internet access (less than 17\% of the sample) are provided with Internet access by RAND through the provision of a WebTV and an Internet subscription (which allows them to open an email account). This eliminates the bias found in many Internet surveys which include only computer users. The setup of the ALP is similar to the long-running CentERpanel in the Netherlands.

Roughly once a month, respondents receive an email with a request to fill out a questionnaire on the Internet. Response rates average 70 to 80 percent. Data are available in real time; that is, after each respondent completes the survey, the data for that interview are immediately uploaded to the database, to which the researcher has access. Upon joining the panel, respondents to the ALP complete an initial survey collecting individual sociodemographic information, work history and household composition information. They are also asked to update their background information each time they log in to respond to a new module.

We designed a module survey that was administered to ALP respondents last June 2009. Apart from already collected socio-demographic and work status information, our module included detailed questions regarding current and past marital statuses including number of years in the current or past relationship and years passed since a marital status change. In addition, for those married or cohabiting with a partner we asked a series of questions aiming to understand how financial responsibilities are divided in the household. These questions asked the respondents to state who is primarily responsible for the following activities: paying the bills, preparing taxes, tracking investments and insurance coverage, making short-term spending/saving plans and making long-term spending saving plans. The respondents could answer "mostly me," "mostly my partner," or "both equally." This survey was merged with financial literacy measures collected in a previous module designed by Hung et. al. (2009a). 


\subsection{Measuring Financial Literacy}

The definitions and measures of financial literacy that have been considered in the literature vary considerably across researchers and studies and have included specific knowledge, the ability or skills to apply that knowledge, perceived knowledge, good financial behavior, or even certain financial experiences. We utilize a measure of financial literacy developed by Hung et al. (2009a, 2009b). It is a comprehensive measure of multiple dimensions of financial literacy and measures underlying financial literacy well, as measured by reliability of the index (Hung et al, 2009b).

The index is based on answers to 23 questions on basic financial concepts, investing, life insurance, and annuities. Specifically, the index included the 13-item scale from Lusardi and Mitchell (2006). These included measuring knowledge on: numeracy, compound interest, and inflation (five items); and stock market, stocks, bonds, mutual funds, and diversification (eight items). It also included six additional items measuring knowledge on the definition of stock, bond, and mutual funds and four items measuring respondent's knowledge about life insurance and annuities. The financial literacy index is constructed using a structural unidimensional model of financial literacy, taking into account the distributional characteristics of the variables. In particular, the model specified the probability of answering each of the test items as a function of the underlying true but unobserved financial literacy. Optimal estimates of the true financial literacy were then obtained maximizing the log pseudo-likelihood function after assuming that the unobserved financial literacy trait was standard normally distributed. ${ }^{4}$

Thus, this financial literacy index is well-suited for our study's goals of quantifying the gender gap of a comprehensive measure of financial literacy and investigating how financial literacy relates to decision-making within a household. Utilizing this index also allows us to avoid problems of multiple inference from many separate measures and simplifies interpretation of our results since we analyze changes in a continuous, normally distributed summary measure of financial literacy. A limitation is that it does not allow us to separately quantify the gender gap in a particular concept of financial literacy. In the research presented here, we normalized the financial literacy index so it has mean zero and standard deviation equal to one.

\footnotetext{
${ }^{4}$ See Hung et.al. (2009b) for a detailed description of how this index measure is constructed.
} 


\subsection{Descriptive Statistics}

Members of the ALP tend to have more education and income than the broader U.S. population, so we report results weighted to be representative of the U.S. population ages 18 and older. Approximately two-thirds of the ALP respondents provided information necessary for construction of the financial literacy index. Although correlated with the different sociodemographic variables, the missing status on this variable was not correlated with gender once we condition on the socio-demographic information. Therefore, we think that the prevalence of missing information on financial literacy does not alter the interpretation of our results.

Table 1 shows weighted summary statistics, by gender, for the respondents with nonmissing values of the financial literacy index. The financial literacy index for women is about 0.7 standard deviations lower than for men $(\mathrm{p}<0.01)$. Women in our sample are younger, are more likely to belong to minority ethnic groups, and they have lower levels of education and income than men. Women are also are more likely to be divorced, widowed or never married than men, and they remain unmarried longer than men. Women are slightly less likely to work than men, and a higher proportion of women have partners with lower education. These differences in demographic characteristics as well as socio-economic characteristics of women compared to men likely explain some of the difference in the financial literacy index.

\section{What Factors Mitigate Gender Differences in Financial Literacy?}

\subsection{Determinants of Financial Literacy}

Table 2 reports the results of multivariate regression analysis of a number of potential factors associated with financial literacy. The dependent variable in each case is the normalized index of financial literacy described above, so that the estimated coefficients represent the effects of covariates in terms of standard deviation increases in financial literacy. Column 1 presents the results of a simple regression of financial literacy on a dummy variable for female. Thus, the coefficient on female represents the raw gender difference in financial literacy, equal to the difference reported in Table 1. Specification 2 adds age and race dummies; although these variables are for the most part statistically significant, they do not have a large effect on the magnitude of the gender difference - reducing it by roughly $9 \%$. Adding socioeconomic 
characteristics (i.e., education and family income) reduces the coefficient on gender an additional $13.5 \%$ (specification 3 ).

Specifications 4 and 5 explore the role of marital status in explaining gender differences in financial literacy. Note that simply including a dummy for whether the respondent is in a couple (married or cohabiting) does not significantly effect the coefficient on female (specification 4). When couple status is disaggregated into finer categories (i.e., couples broken into married or cohabiting; non-couples broken into separated, divorced or widowed), the coefficient on female is further reduced: there is a 25 percent decline in magnitude of the estimate from specification 1 (no covariates) to specification 5. Although current marital status is not strongly correlated with financial literacy, the length of time you have spent in the relationship may be important. Specification 6 adds covariates on length of time in the relationship for those currently married or co-habitating and years since marital disruption for those currently divorced or widowed. We find no effect of years in the relationship on the financial literacy of married individuals relative to never married. Divorced individuals, however, are about 0.30 standard deviations less financially literate than their never married counterparts, and 0.42 standard deviations less financially literate than currently married respondents. Moreover, divorced respondents gain 0.02 standard deviations in financial literacy for every year since their last relationship (making up for their initial deficit in roughly 13.7 years). The negative coefficient on divorced is consistent with marital selection: individuals with lower "ability" are less likely to stay married. On the other hand, the positive coefficient on years since divorce is consistent with marital specialization: previously married respondents with low levels of financial literacy gain knowledge over time as they learn to make financial plans without a partner.

The marital specialization hypothesis has ambiguous predictions for the coefficient on years in current relationship. This is a result of the fact that, among couples that specialize, one partner will develop financial literacy while the other's financial skills will deteriorate. If men tend to specialize in handling finances, then we might expect the coefficient on years in a relationship to be positive for men and negative for women. In the next section we allow coefficients on determinants of financial literacy to differ for men and women. Furthermore, we employ Oaxaca decomposition in order to decompose gender differences into differences due to endowments and differences due to coefficients or production technology (Oaxaca, 1973). 


\subsection{Oaxaca Decomposition}

As noted above, if men and women tend to take on different specialized roles within the household, specifically with respect to financial decision-making and planning, then it is important to allow different effects of marital status and history by gender. More generally, men and women might have different production technologies for financial literacy, so allowing for differential effects may be important for other covariates as well. Panel A of Table 3 presents estimates of a fully interacted version of specification 6 from Table 2. Importantly, including the interaction terms reduces the estimated gender gap in financial literacy to -0.31 standard deviations (the difference between the two constant terms) and the gap is no longer statistically different from zero.

Some surprising findings emerge. For example, the effects of age, race and income on financial literacy are not statistically different for men and women. However, men benefit much more from education than women; indeed, there is no discernible gain to women in terms of financial literacy from graduating high school or attending some college (compared with dropping out of high school). Only college-educated women are more financially literate than women without a high school degree, whereas all levels of education above no high school are associated with higher financial literacy for men. Turning to marital status, married women are significantly more financially literate than unmarried women, which is not the case for married men. In addition, married women are financially more literate on average than married men. Divorced women and men are no less financially literate than never married women and men nor is there a significant difference between the financial literacy levels of divorced men and women. Similar to what we saw in Table 2, specification 6, years since divorce are associated with increases in financial literacy for both men and women. Somewhat surprising is the finding that widowed men are more financially literate than never married men although this declines with years married and years since the widowing occurred. Because the sample of widowed men is small (20 men total), we do not put much weight on these estimates or place an interpretation on them.

Finally, Panel B of Table 3 presents the results of a Oaxaca decomposition of the gender gap in financial literacy into variation due to (a) endowments (e.g., characteristics such as age, education and income), (b) coefficients (i.e., differential effects of characteristics such as age, 
education and income), and (c) the interaction of these two terms. Thus, if we estimate the following regression:

$$
E[y \mid X, d]=d X \beta^{F}+(1-d) X \beta^{M},
$$

where $y$ denotes financial literacy, $X$ is a vector of socioeconomic characteristics and $d$ is a dummy variable for female, then we can compose the gender gap as follows:

$$
E[y \mid d=0]-E[y \mid d=1]=\Delta X \beta^{F}-\Delta \beta E[X \mid d=1]+\Delta X \Delta \beta,
$$

where $\Delta X=E[X \mid d=0]-E[X \mid d=1]$ and $\Delta \beta=\beta^{M}-\beta^{F}$. The first term captures how much of the gender gap is due to differences in characteristics among men and women (e.g., average education) assuming the same "production technology" (here, that of women). This is often referred to as the "explained" part of the decomposition. The second term captures how much of the gender gap is due to differences in coefficients (production technology) assuming men and women tend to have the same characteristics (here again, that of women). The final term is the part of the gap arising from the interaction between endowments and coefficients. Often these last two terms are referred to as the "unexplained" part, but sometimes the interaction term is included within the "explained" part when the decomposition is viewed from the perspective of men serving as the baseline.

Regardless of interpretation, it is clear that the great majority of the gender gap is due to differences in coefficients rather than differences in characteristics between men and women. Thus, for whatever reason, men and women have very different production processes for financial literacy. In the next section, we explore one possible explanation: restricting our attention to couples, we investigate how division of labor for financial decisions within the household is correlated with financial literacy for men and women.

\section{How Do Households Determine Division of Labor for Financial Decision-Making?}

\subsection{Gender Differences in Division of Labor Among Couples}

We asked married and cohabiting respondents who in their household is responsible for the following activities: paying the bills, preparing taxes, tracking investments and insurance coverage, making short-term spending/saving plans (e.g., monthly budget), and making longterm spending/saving plans (e.g., planning for retirement). Response choices were: mostly me, 
both equally and mostly my partner/spouse. The ALP only surveys one respondent per household thus we cannot not match respondents' reports with those of their spouses. Table 4 presents the division of labor reported by coupled respondents for men and women separately. Note that, since both men and women were randomly sampled from the population, then on average an objective measure would reveal the fraction of men's reports of "mostly me" to match the fraction of women's reports of "mostly my partner," and vice versa. Not surprisingly, however, both men and women are more likely to say "mostly me" than "mostly my partner."

Beyond these differences, however, there is a great deal of agreement on who is responsible for what among couples. The proportion of respondents reporting that they share responsibilities equally with their partners is roughly the same for men and women. Moreover, both men and women agree that women are more likely to be responsible for paying the bills. In addition, about half of respondents say they make short- and long-term spending/saving decisions together (with slightly more women saying they are primarily responsible for shortterm spending, which may be hard to differentiate from paying bills). On the other hand, there is some disagreement on where responsibility for paying taxes and tracking investments lies; about half of men say they are primarily responsible, but these responsibilities seem more spread out among couples according to women.

\subsection{How Does Division of Labor Reflect Differences in Financial Literacy?}

Table 5 presents results for the average financial literacy of men and women by division of labor within the household for various activities. An immediately striking result is that the gender gap in financial literacy persists across division of labor categories. For example, among respondents who report that they are primarily responsible for paying the bills, men outperform women by almost three-quarters of a standard deviation on the financial literacy index. The gap tends to be smaller, and in some cases disappear, among men and women who report that their partner is responsible for financial activities.

Table 5 also reports p-values for standard $\mathrm{F}$ tests of equality within gender. If women and men sort into responsibility for financial activities based on financial literacy, then we would expect financial literacy to decrease as one moves from "mostly me" to "mostly my partner." This is clearly the case for men, and the p-values for the $\mathrm{F}$ tests are all less than 0.03 (and in all but one case less than 0.001 ). However, for women financial literacy does not appear to play a 
role in their perception of their financial responsibilities. Only two p-values are less than $0.10-$ preparing taxes and making long-term plans - and the differences in financial literacy do not follow the expected pattern. If anything, less financially literate women are taking on responsibility for those activities.

A possibility is that assortive matching between men and women is confounding correlations between financial responsibility and literacy. That is, what really matters is relative differences in financial literacy within a couple. For example, highly financially literate women may tend to marry highly financially literate men, so these relative differences are not reflected in the raw correlations 5 . We cannot observe relative differences in financial literacy among couples, but we can examine the role of education - both in absolute and relative terms - in determining division of labor in financial decision-making within couples.

\subsection{The Role of Education}

Table 6 displays the average number of financial responsibilities (out of the five activities we presented) taken on mostly by respondents and their partners, respectively, by gender and education. Panel A presents means by absolute level of education, whereas Panel B presents means by education of the respondent relative to his or her partner (more, the same or less). For example, women who completed high school or less on average were responsible for 1.86 financial activities, compared to 1.36 for men of similar education. This pattern is reversed for higher education categories; that is, women who completed at least some college were responsible for fewer activities on average than similarly educated men. Table 6 also reports pvalues for standard $\mathrm{F}$ tests of equality within gender. As before, on average men are responsible for more financial activities as their education increases, whereas no such pattern is discernible for women.

However, when we consider relative education levels within couples, as opposed to absolute education levels, these results do not hold. In fact, women and men with similar education levels relative to their partner tend to take on the same number of financial responsibilities on average. Additionally, both men and women are responsible for more financial activities as their education increases relative to their spouse or partner. This suggests

\footnotetext{
5 The phenomenon that couples sort by wealth, education and other characteristics has been long studied in the literature (see e.g. Becker (1973)).
} 
that relative education differences may trump traditional gender roles when couples determine how to divide up financial responsibilities.

\section{Conclusion}

This paper uses data from the RAND American Life Panel to examine potential explanations for the gender gap in financial literacy including the role of household marital specialization and division of labor among couples. We found that women perform almost 0.7 standard deviations lower than men on our financial literacy index, and the difference is highly significant. We then examined a number of potential factors affecting the observed financial literacy gap. We found that demographic characteristics had a limited effect on the financial literacy gap, whereas controlling for socio-demographic characteristics, current and past marital status reduced the observed gap by around $25 \%$. We found marital selection may be important in explaining the observed gender gap, as well as marital specialization. Finally, we allowed for men and women to have different financial literacy production functions and performed an Oaxaca decomposition analysis. This analysis showed that the great majority of the gender gap is due to differences in coefficients rather than differences in characteristics between men and women. Thus, men and women seem to have very different production processes for financial literacy. Further research is needed to understand why this could be the case.

We did not find strong support for specialization by gender for the financial decisions we study and only a positive correlation between decision-making and financial literacy for males. Instead, we found that decision-making within couples, with regards to paying bills, preparing taxes, tracking investments and making short and long term savings plans, is sensitive to the relative education level of spouses for both women and men. In fact, women and men with similar education levels relative to their partner on average take on the same number of financial responsibilities and both men and women are responsible for more financial activities as their education increases relative to their spouse or partner. 


\section{References}

Becker, G. S. (1973) "A Theory of Marriage: Part I," Journal of Political Economy, University of Chicago Press, vol. 81(4), pages 813-46, July-Aug.

Becker, G. S. (1985) "Human Capital, Effort and the Sexual Division of Labor", Journal of Labor Economics, Vol. 3, No.1, 33-58.

Bergstrom, T. (1997). A Survey of Theory of the Family. Handbook of Family and Population Economics, Elsevier.

Bernheim, B. Douglas and Daniel M. Garrett (2003), "The effects of Financial Education in the Workplace: Evidence from a Survey of Households." Journal of Public Economics 87 (7/8): 1487-1519.

Bernheim, B. Douglas \& Garrett, Daniel M. \& Maki, Dean M., (2001), "Education and saving:: The long-term effects of high school financial curriculum mandates," Journal of Public Economics, 80(3): 435-465, June.

Chen H. and R. P. Volpe (2002), “Gender Differences in Personal Financial Literacy Among College Students", Financial Services Review, 11, 283-307.

Clark, R.L., M. B. d'Ambrosio, A. A. McDermed and K. Sawant (2004), "Sex Differences, Financial Education, and Retirement Goals" in Ed. O.S. Mitchell and S. P. Utkus, Pension Design and Structure: New Lessons From Behavioral Finance, Oxford University Press.

Hung A., Parker A. M. and J. Yoong (2009a), "Defining and Measuring Financial Literacy", RAND Working paper WR-708.

Hung A., Meijer E., Mihaly K. and J. Yoong (2009b), “Building Up, Spending Down: Financial Literacy, Retirement Savings Management, and Decumulation”, RAND Working paper WR-712.

Levine P.B., O.S. Michell, and J.W.R. Phillips. (2002) “Worklife Determinants of Retirement Income: Differences Across Men and Women” in Ed. O.S. Michell, Z. Bodie, P.B. Hammond and S. Zeldes, Innovations in Retirement Financing, University of Pennsylvania Press. 
Lusardi A. and O. Mitchell (2006), "Financial Literacy and Planning Implications for Retirement Wellbeing”, Wharton School, University of Pennsylvania, Pension Research Council Working Paper no. 1.

Lusardi, Annamaria, and Olivia S. Mitchell (2007), "Financial Literacy and Retirement Preparedness: Evidence and Implications for Financial Education.” Business Economics, 42(1): 35-44.

Lusardi A. and O. Mitchell (2008), "Planning and Financial Literacy: How Do Women Fare?", American Economic Review, 98(2), 413-417.

Oaxaca, R. (1973), "Male-Female Wage Differentials in Urban Labor Markets", International Economic Review, 14, 693-709.

Weir D.R. and R.J. Willis (2000), "Prospects for Widow Poverty in the Finances of Married Couples in the HRS", in O. Mitchell, P. B. Hammond, and A. Rappaport, eds. Forecasting Retirement Needs and Retirement Wealth. (Philadelphia: University of Pennsylvania Press), 208-234.

Zissimopoulos, J. B. Karney and A. Rauer (2008), "Marital Histories and Economic WellBeing,” MRRC Working Paper WP2008-180, 2008. 


\begin{tabular}{|c|c|c|c|c|c|c|c|}
\hline & \multicolumn{3}{|c|}{ Female } & \multicolumn{3}{|c|}{ Male } & \multirow[b]{2}{*}{ Diff. } \\
\hline & $\mathbf{N}$ & Mean & Std. dev. & $\mathbf{N}$ & Mean & Std. dev. & \\
\hline $\begin{array}{l}\text { Financial literacy index } \\
\text { Age }\end{array}$ & 844 & -0.537 & 0.965 & 678 & 0.158 & 0.978 & $-0.695^{\star * \star}$ \\
\hline $18-35$ & 844 & 0.199 & 0.400 & 678 & 0.159 & 0.366 & $0.040^{* *}$ \\
\hline $36-50$ & 844 & 0.355 & 0.479 & 678 & 0.338 & 0.473 & 0.017 \\
\hline $51-65$ & 844 & 0.257 & 0.437 & 678 & 0.275 & 0.447 & -0.018 \\
\hline $66+$ & 844 & 0.189 & 0.391 & 678 & 0.228 & 0.420 & -0.039 \\
\hline \multicolumn{8}{|l|}{ Race } \\
\hline White & 844 & 0.750 & 0.433 & 678 & 0.834 & 0.372 & $-0.084^{* * *}$ \\
\hline Black & 844 & 0.137 & 0.344 & 678 & 0.088 & 0.284 & $0.048^{* * *}$ \\
\hline Other & 844 & 0.016 & 0.125 & 678 & 0.009 & 0.097 & 0.006 \\
\hline \multicolumn{8}{|l|}{ Education } \\
\hline High school dropout & 844 & 0.050 & 0.219 & 678 & 0.040 & 0.197 & 0.010 \\
\hline High school graduate & 844 & 0.356 & 0.479 & 678 & 0.281 & 0.450 & $0.075^{* * *}$ \\
\hline Some college & 844 & 0.250 & 0.433 & 678 & 0.262 & 0.440 & -0.013 \\
\hline College graduate & 844 & 0.344 & 0.475 & 678 & 0.416 & 0.493 & $-0.073^{* * *}$ \\
\hline \multicolumn{8}{|l|}{ Income } \\
\hline$<\$ 35 \mathrm{~K}$ & 844 & 0.273 & 0.446 & 678 & 0.211 & 0.408 & $0.063^{* * *}$ \\
\hline$\$ 35 \mathrm{~K}-\$ 60 \mathrm{~K}$ & 844 & 0.278 & 0.448 & 678 & 0.248 & 0.432 & 0.029 \\
\hline$\$ 60 \mathrm{~K}-\$ 90 \mathrm{~K}$ & 844 & 0.272 & 0.445 & 678 & 0.305 & 0.461 & -0.033 \\
\hline$>\$ 90 \mathrm{~K}$ & 844 & 0.177 & 0.382 & 678 & 0.236 & 0.425 & $-0.059^{* * *}$ \\
\hline \multicolumn{8}{|l|}{ Marital status } \\
\hline In a couple & 844 & 0.524 & 0.500 & 678 & 0.664 & 0.473 & $-0.140^{* * *}$ \\
\hline Married & 832 & 0.481 & 0.500 & 674 & 0.628 & 0.484 & $-0.147^{* * *}$ \\
\hline Cohabiting & 832 & 0.047 & 0.211 & 674 & 0.039 & 0.195 & 0.007 \\
\hline Separated & 832 & 0.013 & 0.112 & 674 & 0.013 & 0.113 & 0.000 \\
\hline Divorced & 832 & 0.156 & 0.363 & 674 & 0.115 & 0.319 & $0.041^{* *}$ \\
\hline Widowed & 832 & 0.076 & 0.265 & 674 & 0.035 & 0.183 & $0.041^{* * *}$ \\
\hline Never married & 832 & 0.227 & 0.419 & 674 & 0.170 & 0.376 & $0.057^{* * *}$ \\
\hline \multicolumn{8}{|l|}{ Marital history } \\
\hline Years in current relationship & 519 & 20.930 & 14.485 & 490 & 23.277 & 15.637 & $-2.347^{* *}$ \\
\hline Years in last relationship & 199 & 17.468 & 13.747 & 105 & 17.787 & 15.492 & -0.319 \\
\hline Years since last relationship & 201 & 14.707 & 10.448 & 105 & 11.412 & 10.424 & $3.295^{* * *}$ \\
\hline \multicolumn{8}{|l|}{ HH size not incl. self/partner } \\
\hline No dependents & 844 & 0.465 & 0.499 & 678 & 0.535 & 0.499 & $-0.007^{* * *}$ \\
\hline Number of dependents (if $>0$ ) & 402 & 2.178 & 1.333 & 290 & 2.142 & 1.120 & 0.036 \\
\hline Working for pay & 820 & 0.642 & 0.480 & 651 & 0.693 & 0.461 & $-0.051^{* *}$ \\
\hline \multicolumn{8}{|l|}{ Education relative to partner } \\
\hline Partner has more & 519 & 0.169 & 0.375 & 490 & 0.189 & 0.392 & -0.020 \\
\hline Both same & 519 & 0.590 & 0.492 & 490 & 0.637 & 0.481 & -0.047 \\
\hline Partner has less & 519 & 0.242 & 0.429 & 490 & 0.174 & 0.380 & $0.068^{* * *}$ \\
\hline
\end{tabular}




\begin{tabular}{|c|c|c|c|c|c|c|c|c|}
\hline \multicolumn{9}{|c|}{$\begin{array}{l}\text { Table 2. Financial Literacy Regressions } \\
\end{array}$} \\
\hline & \multirow[b]{3}{*}{ (1) } & \multirow[b]{3}{*}{ (2) } & \multirow[b]{3}{*}{ (3) } & \multirow[b]{3}{*}{ (4) } & \multirow[b]{3}{*}{ (5) } & \multicolumn{3}{|c|}{ (6) } \\
\hline & & & & & & \multirow[b]{2}{*}{ Level } & \multicolumn{2}{|c|}{ Interactions } \\
\hline & & & & & & & Yrs in rel. & Yrs since \\
\hline Female & $\begin{array}{c}-0.695^{\star * *} \\
(0050)\end{array}$ & $\begin{array}{c}-0.632^{* * *} \\
(0.047)\end{array}$ & $\begin{array}{c}-0.539^{* * *} \\
(0.042)\end{array}$ & $\begin{array}{c}-0.532^{* * *} \\
(0.043)\end{array}$ & $\begin{array}{c}-0.522^{* * *} \\
(0.043)\end{array}$ & $\begin{array}{c}-0.538^{* * *} \\
(0.043)\end{array}$ & & \\
\hline \multirow[t]{2}{*}{ Age $36-50$} & & $0.500^{* * *}$ & $0.339^{* * *}$ & $0.328^{* * *}$ & $0.317^{* * *}$ & $0.324^{* * *}$ & & \\
\hline & & $(0.068)$ & $(0.062)$ & $(0.062)$ & $(0.065)$ & $(0.065)$ & & \\
\hline \multirow[t]{2}{*}{ Age 51-65 } & & $0.724^{* * *}$ & $0.587^{* * *}$ & $0.580^{* * *}$ & $0.566^{* * *}$ & $0.563^{* * *}$ & & \\
\hline & & $(0.072)$ & $(0.065)$ & $(0.065)$ & $(0.069)$ & $(0.075)$ & & \\
\hline \multirow[t]{2}{*}{ Age $66+$} & & $0.830^{* * *}$ & $0.822^{* * *}$ & $0.815^{* * *}$ & $0.822^{* * *}$ & $0.790^{* * *}$ & & \\
\hline & & $(0.077)$ & $(0.070)$ & $(0.070)$ & $(0.077)$ & $(0.099)$ & & \\
\hline \multirow[t]{2}{*}{ White } & & 0.113 & $0.311^{* * *}$ & $0.312^{* * *}$ & $0.311^{* * *}$ & $0.303^{* * *}$ & & \\
\hline & & $(0.081)$ & $(0.074)$ & $(0.074)$ & $(0.074)$ & $(0.074)$ & & \\
\hline \multirow[t]{2}{*}{ Black } & & $-0.341^{* * *}$ & 0.00675 & 0.0157 & 0.0154 & -0.0113 & & \\
\hline & & $(0.100)$ & $(0.093)$ & $(0.094)$ & $(0.094)$ & $(0.094)$ & & \\
\hline \multirow[t]{2}{*}{ High school graduate } & & & $0.270^{* *}$ & $0.267^{* \star}$ & $0.239^{\star *}$ & 0.213 & & \\
\hline & & & $(0.110)$ & $(0.110)$ & $(0.110)$ & $(0.110)$ & & \\
\hline \multirow[t]{2}{*}{ Some college } & & & $0.459^{* * *}$ & $0.458^{* * *}$ & $0.424^{* * *}$ & $0.399 * * *$ & & \\
\hline & & & $(0.110)$ & $(0.110)$ & $(0.110)$ & $(0.110)$ & & \\
\hline \multirow[t]{2}{*}{ College graduate } & & & $0.844^{* * *}$ & $0.854^{* * *}$ & $0.828^{* * *}$ & $0.807^{* * *}$ & & \\
\hline & & & $(0.110)$ & $(0.110)$ & $(0.110)$ & $(0.120)$ & & \\
\hline \multirow[t]{2}{*}{ Income $\$ 35-60 \mathrm{~K}$} & & & $0.282^{* * *}$ & $0.267^{* * *}$ & $0.262^{* * *}$ & $0.287^{* * *}$ & & \\
\hline & & & $(0.061)$ & $(0.062)$ & $(0.062)$ & $(0.063)$ & & \\
\hline \multirow[t]{2}{*}{ Income $\$ 60-90 \mathrm{~K}$} & & & $0.459^{* * *}$ & $0.435^{* * *}$ & $0.414^{* * *}$ & $0.417^{* * *}$ & & \\
\hline & & & $(0.062)$ & $(0.064)$ & $(0.065)$ & $(0.065)$ & & \\
\hline \multirow[t]{2}{*}{ Income $>\$ 60 \mathrm{~K}$} & & & $0.675^{* * *}$ & $0.642^{* * *}$ & $0.634^{* * *}$ & $0.635^{* * *}$ & & \\
\hline & & & $(0.071)$ & $(0.075)$ & $(0.076)$ & $(0.076)$ & & \\
\hline In a couple & & & & $\begin{array}{c}0.063 \\
(0.047)\end{array}$ & & & & \\
\hline \multirow[t]{2}{*}{ Married } & & & & & 0.0693 & 0.119 & -0.002 & \\
\hline & & & & & $(0.062)$ & $(0.077)$ & $(0.003)$ & \\
\hline \multirow[t]{2}{*}{ Cohabiting } & & & & & -0.188 & -0.135 & -0.008 & \\
\hline & & & & & $(0.110)$ & $(0.150)$ & $(0.013)$ & \\
\hline \multirow[t]{2}{*}{ Divorced } & & & & & 0.043 & $-0.302^{* *}$ & 0.001 & $0.022^{* * *}$ \\
\hline & & & & & $(0.078)$ & $(0.140)$ & $(0.007)$ & $(0.006)$ \\
\hline Widowed & & & & & -0.143 & 0.213 & -0.003 & -0.021 \\
\hline & & & & & $(0.110)$ & $(0.310)$ & $(0.007)$ & $(0.012)$ \\
\hline Constant & $\begin{array}{c}0.158^{\star \star *} \\
(0.037)\end{array}$ & $\begin{array}{c}-0.463^{\star * *} \\
(0.092)\end{array}$ & $\begin{array}{c}-1.482^{* \star *} \\
(0.130)\end{array}$ & $\mid \begin{array}{c}-1.502^{* * *} \\
(0.130)\end{array}$ & $\begin{array}{c}-1.448^{* * *} \\
(0.130)\end{array}$ & $\begin{array}{c}-1.412^{* * *} \\
(0.130)\end{array}$ & & \\
\hline Observations & 1,522 & 1,522 & 1,522 & 1,522 & 1,506 & 1,504 & & \\
\hline & 0.11 & 0.22 & 0.38 & 0.38 & 0.39 & 0.40 & & \\
\hline $\begin{array}{l}\text { Notes: Standard err } \\
\text { standardized financi } \\
\text { number of observati }\end{array}$ & arenthe & s. ${ }^{* * *} p<$ & $\begin{array}{l}.01,{ }^{* *} p \\
\text { control fo }\end{array}$ & $\begin{array}{l}0.05 \text {. Dat } \\
\text { separate }\end{array}$ & $\begin{array}{l}\text { are weig } \\
\text { but do no }\end{array}$ & $\begin{array}{l}\text { ted. Depe } \\
\text { report du }\end{array}$ & ent varic & is \\
\hline
\end{tabular}


Table 3. Oaxaca Decomposition of Gender Gap

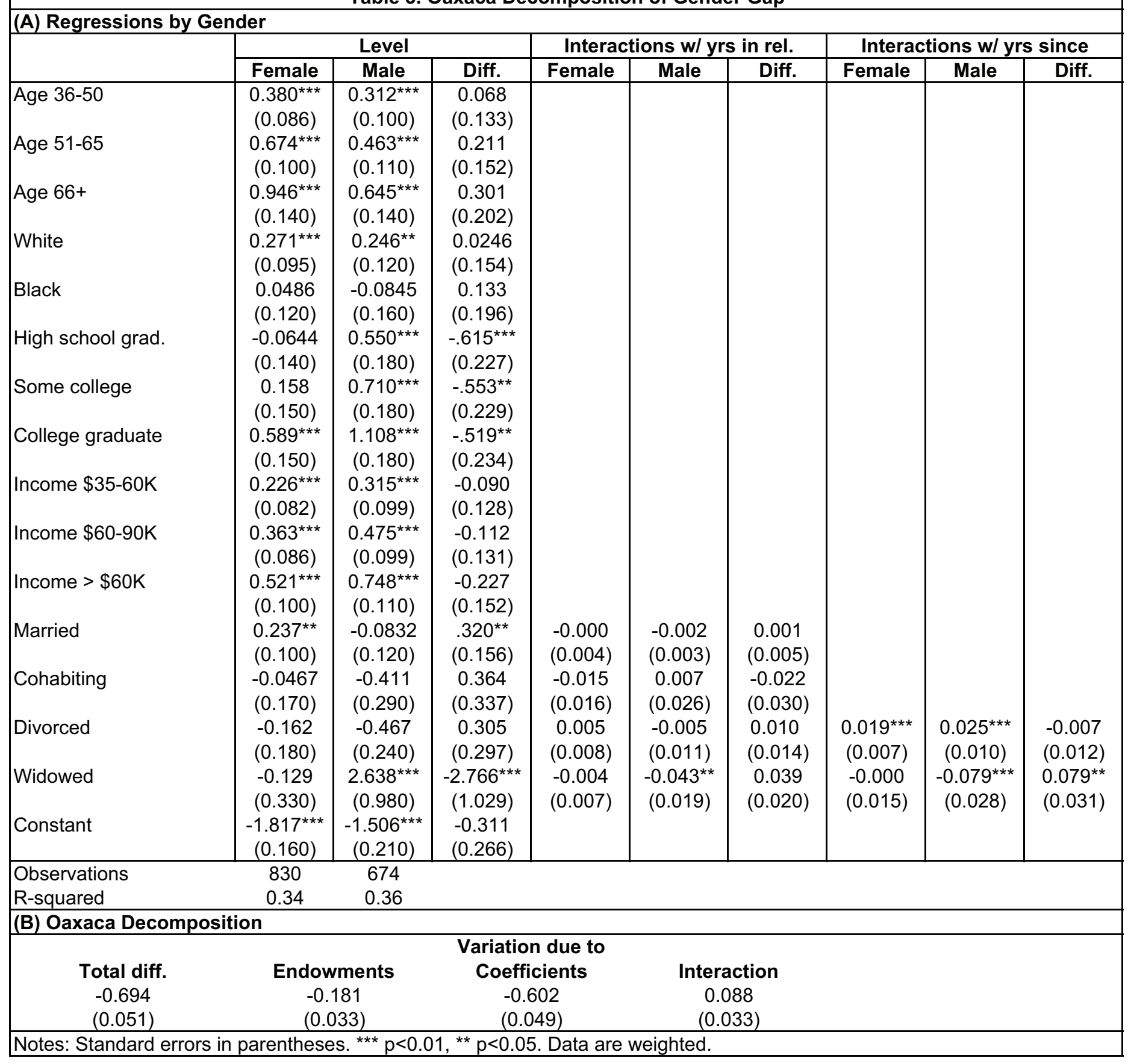




\begin{tabular}{|c|c|c|c|c|c|c|}
\hline \multicolumn{7}{|c|}{ Table 4. Division of Labor Among Couples, Reported by Gender } \\
\hline \multirow[b]{2}{*}{ Mostly } & \multicolumn{3}{|c|}{ Female } & \multicolumn{3}{|c|}{ Male } \\
\hline & $\mathrm{Me}$ & Equal & Partner & Me & Equal & Partner \\
\hline Paying bills & $51.2 \%$ & $22.1 \%$ & $26.7 \%$ & $36.9 \%$ & $22.1 \%$ & $41.1 \%$ \\
\hline Paying taxes & $36.5 \%$ & $29.0 \%$ & $34.5 \%$ & $48.6 \%$ & $24.6 \%$ & $26.8 \%$ \\
\hline Tracking investments/insurance & $32.8 \%$ & $34.8 \%$ & $32.4 \%$ & $49.2 \%$ & $32.2 \%$ & $18.6 \%$ \\
\hline Making short-term spending/saving plans & $43.2 \%$ & $44.2 \%$ & $12.6 \%$ & $24.6 \%$ & $47.5 \%$ & $27.8 \%$ \\
\hline Making long-term spending/saving plans & $26.2 \%$ & $51.5 \%$ & $22.3 \%$ & $33.8 \%$ & $49.2 \%$ & $17.0 \%$ \\
\hline
\end{tabular}




\begin{tabular}{|l|c|c|c|}
\hline \multicolumn{4}{|c|}{ Table 5. Mean Financial Literacy by Gender \& Role in Household Decision-Making } \\
\hline \multicolumn{1}{|c|}{} & Female & Male & Diff. \\
\hline Paying the bills & & & \\
Mostly me & -0.366 & 0.380 & $-0.746^{* * *}$ \\
Both equally & -0.512 & 0.129 & $-0.641^{* * *}$ \\
Mostly my partner & -0.281 & 0.143 & $-0.423^{* * *}$ \\
F test of equality & 0.144 & 0.025 & \\
\hline Preparing taxes & & & \\
Mostly me & -0.394 & 0.486 & $-0.880^{* * *}$ \\
Both equally & -0.529 & -0.048 & $-0.481^{* * *}$ \\
Mostly my partner & -0.225 & -0.099 & -0.126 \\
F test of equality & 0.014 & 0.000 & \\
\hline Tracking investments and insurance coverage & & & \\
Mostly me & -0.442 & 0.522 & $-0.964^{* * *}$ \\
Both equally & -0.390 & 0.036 & $-0.426^{* * *}$ \\
Mostly my partner & -0.270 & -0.376 & 0.106 \\
F test of equality & 0.217 & 0.000 & \\
\hline Making short-term spending/saving plans & & & \\
Mostly me & -0.396 & 0.422 & $-0.818^{* * *}$ \\
Both equally & -0.341 & 0.277 & $-0.618^{* * *}$ \\
Mostly my partner & -0.441 & -0.071 & $-0.370^{* *}$ \\
F test of equality & 0.707 & 0.000 & \\
\hline Making long-term spending/saving plans & & & \\
Mostly me & -0.639 & 0.515 & $-1.154^{* * *}$ \\
Both equally & -0.289 & 0.220 & $-0.509^{* * *}$ \\
Mostly my partner & -0.247 & -0.558 & 0.312 \\
F test of equality & 0.000 & 0.000 & \\
\hline Notes: *** p<0.01, ** p<0.05. Data are weighted. Financial literacy index is standardized. \\
\hline
\end{tabular}




\section{Table 6. Division of Labor by Gender \& Education}

\begin{tabular}{|l|c|c|c|}
\hline (A) Absolute Education & Female & Male & Diff. \\
\hline Mean count "mostly me" & 1.861 & 1.363 & $0.498^{* *}$ \\
Less than/equal to high school & 1.842 & 2.131 & -0.289 \\
Some college & 2.009 & 2.425 & $-0.416^{* * *}$ \\
College graduate & 0.574 & 0.000 & \\
F test of equality (p-value) & & & \\
\hline Mean count "mostly my partner" & 1.234 & 1.785 & $-0.551^{* * *}$ \\
Less than/equal to high school & 1.423 & 1.051 & $0.372^{* * *}$ \\
Some college & 1.208 & 0.939 & $0.269^{* *}$ \\
College graduate & 0.260 & 0.000 & \\
F test of equality (p-value) & & & \\
\hline (B) Relative Education & & & \\
\hline Mean count "mostly me" & 1.357 & 1.393 & -0.036 \\
Partner has more education & 1.822 & 1.936 & -0.114 \\
Partner has same education & 2.881 & 2.518 & 0.363 \\
Partner has less education & 0.000 & 0.000 & \\
F test of equality (p-value) & & & \\
\hline Mean count "mostly my partner" & 1.690 & 1.492 & 0.197 \\
Partner has more education & 1.319 & 1.391 & -0.072 \\
Partner has same education & 0.592 & 0.781 & -0.190 \\
Partner has less education & 0.000 & 0.001 & \\
F test of equality (p-value) & & & \\
\hline Notes: ${ }^{* * *} p<0.01,{ }^{* *} p<0.05$. Count is out of 5 items. Data are weighted, include those missing \\
financial literacy index.
\end{tabular}

